\title{
The Psychological Effect of Uploading Food Picture on Social Media to Willingness to Dine Out
}

\author{
*Novia Dwi Resti, Mustika Sufiati Purwanegara \\ School of Business and Management, Institute Technology Bandung, Indonesia \\ *kiki.novia@sbm-itb.ac.id
}

\begin{abstract}
Lately, people like to capture food picture and post to social media. They share, recommend and critic the food and restaurant to other social media users. Based on exploratory research findings, this phenomenon is assumed having a relation with personality traits, self-concepts and perception of social media users. This paper aims to investigate the effect of restaurant attractiveness, personality, selfconcepts, self-control, and perception to willingness to dine out. Qualitative studies are carried out to get the indicators for designing questionnaires and afterward the questionnaires are distributed by survey. Sample size for qualitative research is 12 respondents who like to post food picture on social media and 102 social media users in Indonesia as respondents for survey. Collected data are analyzed using multivariate analysis. The finding shows that restautant attractiveness, self-concepts, and consumer perception have positive effect to consumer's willingness to dine out after looking at the posted food picture on social media. Implication of this research can help manager of restaurant or cafe to plan marketing program based on consumer personality and other psychological concepts.
\end{abstract}

Keywords: Personality, self-concepts, perception, willingness to dine out, social media

\section{Introduction}

Social media is one of the most popular needs among internet user. It is defined as "online applications, platforms and media which aim to facilitate interactions, collaborations and the sharing of content" (Universal Maccann International, 2008). Online social media possibly used to contact to other users within the system and let public knows their profile (Boyd and Ellison, 2007). Big amount of social media users, make social media become variety, such as Facebook, Twitter, Path and Instagram. What people shared on their private social media is different. Social media user can share status like what they feel, photos like what they do, what they eat, place they visit and joke, document, music and share links. Various photos were sent and share in social media to attract and inform other user about what people do, what people look like, what people wear, what people interested in and what people eat. People like to capture their food picture, send and share it to social media. This picture will be seen by other social media users, some will be attracted to comment, try the food, visit the restaurant, recommend, dislike or even do nothing. These perceptions about food picture, which is shared on social media, are different for everyone. Several previous studies have been conducted about consumer's perception, purchasing behaviour, consumer's psychology, purchase intention related to the hotel and restaurant industry (Dube et al., 1994; Fu and Parks, 2001; Tam, 2004). Company needs to deliver good services and products to the consumers, one of the way is by understanding consumers perception and their characteristic, this will lead restaurant business to success (Rahman, 2012). Consumer behaviour not only related in buying and using product, but also the social and psychological factors that influence action as well (Carman, 1990).

According to study by Shwu-Ing (2003), buying decision is influenced by four major psychological factors: motivation, perception, learning, and beliefs/attitude. Some researchers also differed in influencing factors into internal and external factors (Kaufman, 2002; Shwu-Ing, 2003). In this study internal factors determine as personality, self - concept and perception of consumer, and external factors as stimuli from the company named restaurant attractiveness. Based to Yoo et al. (2000); Pappu and Quester (2006) price, store image, distribution insanity, advertising spending, and price promotion of the marketing mix are the determining factors in consumer perception of the marketing mix. This paper aims to investigate the effect of external and internal factor of consumer to their willingness to dine in restaurant. In this case social media has important role to determine consumer's perception to dine out. Social media have practical cognitive function in stimulating product and service choice (Palmer and Lewis, 2009). Effect of restaurant attractiveness to personality, self - concept and self - control measured, these self - concept to consumer's perception and indirectly to willingness to dine out. 


\section{Literature Review}

Restaurant Attractiveness: Restaurant attractiveness will determine good or bad service that consumer experienced. Change in attractiveness triggered by restaurant's action or by change in competition's market offering (Andreassen and Lervik, 1999) for example change in consumer service. Restaurant attractiveness defined as what restaurant offered that attract consumer. Previous research mention some aspects of restaurant attractiveness for restaurant industry such as food, atmospheres and service (Dulen, 1999; Susskind and Chan, 2000). Based on Dullen (1999) food, physical environment (decor) and service is major feature that attract consumer to dine in restaurant. Physical environment of restaurant can increase consumer's good or bad perception (Susskind and Chan, 2000). Physical environment can bring joyfulness, excitement, or relaxation to the consumer is feeling (Namkung and Jang, 2007). Not only restaurant environment can attracts consumer, satisfy consumer also attract others to dine in restaurant by giving good recommendation. Online word of mouth and the powerful influence of social environment have important influence in marketing promotion (Indrupati and Henari, 2012). Consumer attract to well-known brand easily ( Rajagopal, 2006). Brand is important and affects consumer's decision buying process (Aaker, 1996). Advertising is used to introduce product and can be used to create brand association to consumer (Rajagopal, 2006). Advertising can attract consumer by communicating what company's offer to satisfy consumer. Based on literature review, we hypothesized that:

$H_{1 a} \quad$ Restaurant attractiveness will significantly affect the consumer perception.

$H_{1 b} \quad$ Restaurant attractiveness will significantly affect willingness to dine out.

Personality: Personality defined as the way people react and interact with others (Robbins, 2005). Personality shows the pattern of individual thoughts, emotions and behavior as characteristic that differ to others (McShane and Von Glinow, 2010). Based on Gosling et al (2003) personality can be differed into five : (1) openness to experience : adventure, variety of experience, unusual idea and it reflects intellectual curiosity (2) conscientiousness : it shows self discipline, well-planned, act dutifully and aim for achievement (3) extraversion : it shows positive emotions, engaged to social activity, energetic and action-oriented individual (4)agreeableness : it show compassionate and cooperative to others (5) neuroticism : it shows negative emotion such as anger, anxiety and depression. Based on literature, we hypothesized that:

$\mathrm{H}_{2} \quad$ Personality will significantly affect consumer perception.

Self-Concept: Self-concept has been defined as: "the totality of an individual's thoughts and feeling having reference to himself as an object" (Rosenberg, 1979). Self-concept reflected appraisals (the self is formed around other's perception) ; self attribution (inferred from own behaviour) and psychological centrality ("hierarchical organization") (Rosenberg, 1979 ; Sirgy, 1982). Self - concept represent the way individuals view themselves and the self-concept belong to one's characteristics (Hogg et al, 2000). Social and situational factors influence selves (Greenwald, 1989). We hypothesized that:

$\mathrm{H}_{3} \quad$ Self - concept will significantly affect consumer perception.

Self - Control: Self - control can maintain one's perception (Lee and Allaway, 2002). According to Averill's (1973) concept about behaviour control, controllability determined services and products consumer wants to buy and it will influence theeir perception as well flexibility of thetr decision to commit.We hypothesize that:

$\mathrm{H}_{4} \quad$ Self-control will significantly affect consumer perception.

Perception: Perception is process by which an individual selects, organizes and interprets stimuli into their personal view (Schiffman and Kanuk (2000). Perception process included exposure, attention and interpretation (Solomon, 2011). Good or bad services that consumer experienced will determine consumer perception about product, service and image of company in the future (Andreassen and Lervik, 1999). Next, consumer perception will have an impact on consumer satisfaction and commitment (Andreassen and Olsen, 2008). Based on Johnson (2001) cumulative satisfaction related to commitment. Consumer perception on the quality of a firm evaluated by price, image, reputation and so on (Olson and Jacoby, 1972; Olson, 1977; Parasuraman et al., 1988). We hypothesized:

$\mathrm{H}_{5} \quad$ Consumer perception significantly affect willingness to dine out

Willingness to Dine Out: Previous study about dining in restaurant by Kivela et al (1999) examined that attributes that important to consumer to dine in restaurant are: food factor, service factor, ambience factor, convenience factor and what restaurant offers. Customer willing to dine out because of several 
reason, it can be external and internal factors (Kaufman, 2002; Shwu-Ing, 2003). The model from psychology and marketing thus give a clue to our consuming activities (Andersson and Mossberg, 2004). Customers are willing to dine out if they have intention, or they have ever eaten in restaurant. Their intention can be proved by searching for information about restaurant or looking for companion and desire to visit new restaurant. These indicators mentioned based on the result of interview to some social media user who like to dine out.

\section{Methodology}

Qualitative study was conducted to get prime factor that can influence consumer behavior. Based on literature review and qualitative study, a questionnaire designed. A questionnaire containing all of the variable of measurement used in this study distributed to social media users who ever posted food picture or ever seen food picture in their private social media. Sample sizes who have filled in the survey are 102. In this study, specific social media did not consider. Here are below the table of result of respondent's profile:

Table 1: Respondent's Profile

\begin{tabular}{|c|c|c|c|c|}
\hline Category & & Number & Percentage & Total \\
\hline \multirow{2}{*}{ Gender } & Male & 54 & $52,94 \%$ & \multirow{2}{*}{102} \\
\hline & Female & 48 & $47,06 \%$ & \\
\hline \multirow{6}{*}{ Age } & $<15$ & 0 & $0,00 \%$ & \multirow{6}{*}{102} \\
\hline & $>15-20$ & 5 & $4,90 \%$ & \\
\hline & $>20-30$ & 91 & $89,22 \%$ & \\
\hline & $>30-50$ & 4 & $3,92 \%$ & \\
\hline & $>50$ & 2 & $1,96 \%$ & \\
\hline & Java & 69 & $67,65 \%$ & \\
\hline \multirow{5}{*}{ Location } & Sumatra & 26 & $25,49 \%$ & \multirow{5}{*}{102} \\
\hline & Kalimantan & 3 & $2,94 \%$ & \\
\hline & Sulawesi & 1 & $0,98 \%$ & \\
\hline & Bali & 3 & $2,94 \%$ & \\
\hline & Others & 1 & $0,98 \%$ & \\
\hline \multirow{7}{*}{ Education } & Elementary & 0 & $0,00 \%$ & \multirow{8}{*}{102} \\
\hline & Junior High & 0 & $0,00 \%$ & \\
\hline & Senior High & 23 & $22,55 \%$ & \\
\hline & Diploma & 3 & $2,94 \%$ & \\
\hline & Bachelor & 73 & $71,57 \%$ & \\
\hline & Master & 2 & $1,96 \%$ & \\
\hline & Doctor & 1 & $0,98 \%$ & \\
\hline \multirow{5}{*}{$\begin{array}{l}\text { Expenditure } \\
\text { Rupiah) }\end{array}$} & $<500,000$ & 2 & $1,96 \%$ & \\
\hline & $500,000-1,000,000$ & 20 & $19,61 \%$ & \multirow{4}{*}{102} \\
\hline & $>1,000,000-2,500,000$ & 39 & $38,24 \%$ & \\
\hline & $>2,500,000-5,000,000$ & 30 & $29,41 \%$ & \\
\hline & $>5,000,000$ & 11 & $10,78 \%$ & \\
\hline \multirow{4}{*}{$\begin{array}{l}\text { Duration Access } \\
\text { Social Media }\end{array}$} & $<1$ hour & 32 & $31,37 \%$ & \multirow{4}{*}{102} \\
\hline & 1-3 hours & 31 & $30,39 \%$ & \\
\hline & $>3-5$ hours & 21 & $20,59 \%$ & \\
\hline & $>5$ hours & 18 & $17,65 \%$ & \\
\hline \multirow{6}{*}{$\begin{array}{l}\text { Number of Social } \\
\text { Media Account }\end{array}$} & 1 account & 21 & $20,59 \%$ & \multirow{6}{*}{102} \\
\hline & 2 accounts & 25 & $24,51 \%$ & \\
\hline & 3 accounts & 28 & $27,45 \%$ & \\
\hline & 4 accounts & 14 & $13,73 \%$ & \\
\hline & 5 accounts & 8 & $7,84 \%$ & \\
\hline & $>5$ accounts & 6 & $5.88 \%$ & \\
\hline
\end{tabular}

According to Table 1 most of respondents are bachelor degree, lived in Java Island and in range of age more than 20 to 30 . 
Measures: Personality were measured using 12 items adapt to Ten Item Personality Inventory (TIPI) by (Gosling et al, 2003). The TIPI classified personality into 5 groups, openness to experience, conscientiousness, extraversion, agreeableness and neuroticism. Based on this classification 12 items modified to measure personality. Restaurant attractiveness, self - concept, self - control and consumer perception were measured using the result of interview. The items validated using Factor Analysis. Five point Likert scale used to measure these variables. To get keyword of restaurant attractiveness, the question asked to the respondent is: What's attract you to dine in restaurant? The most answers are its environment, brand, other's recommendation, and advertising. Self-concept consists of 6 items, which developed from result of in-depth interview, which ask about what they want to achieve and how important public confession is. Statement of this variables consists of self-existence, public confession, being point of attention, self-prestige, and show off. Self - control consists of four statements that examine consumer can control their own feeling, desire and behaviour. Consumer perception was measured by four statements which develop by the respondent explanation about picture that describe a girl took photo of her food and post the photo to social media. Willingness to dine out was measured by using 6 items, which adapted from the result of interview. The question given to respondent, how do you notice that you willing to dine out? Example of statements used in the questionnaire are willing to dine out, like to dine out, ask accompanies to dine out, recommend others to dine out, attract to dine in new restaurant, and search information about restaurant before dine out. Five point Likert scale used to measure these variables.

Validity and Reliability: Validity test was measured by using Exploratory Factor Analysis. According to Hair et al (2006), only factor loading minimal .4 are considered to meet minimum level for interpretation of structure. From the result of exploratory factor analysis, 4 personalities extracted. Therefore, after reducing variable, which are significant, items for personality, consist of 4 items such as: social activity likeliness, energetic personality, good speaking skill, friendly personality. All of this items belong to one factor called social personality. Detail information about validity and reliability of variable will be explain in the following table. Restaurant attractiveness, two components extracted named attractive popularity which consist of 4 items such as : attractive restaurant's environment, recommendation from others, attractive popularity, brand consideration and second component named attractive advertising which consist of importance of advertising and advertising attracted. Restaurant attractiveness used to measure factor that make consumer consider about restaurant. Self-concept, self-control, consumer perception and willingness to dine out validated into one factor.

Table 2: Validity of Items Questionnaire

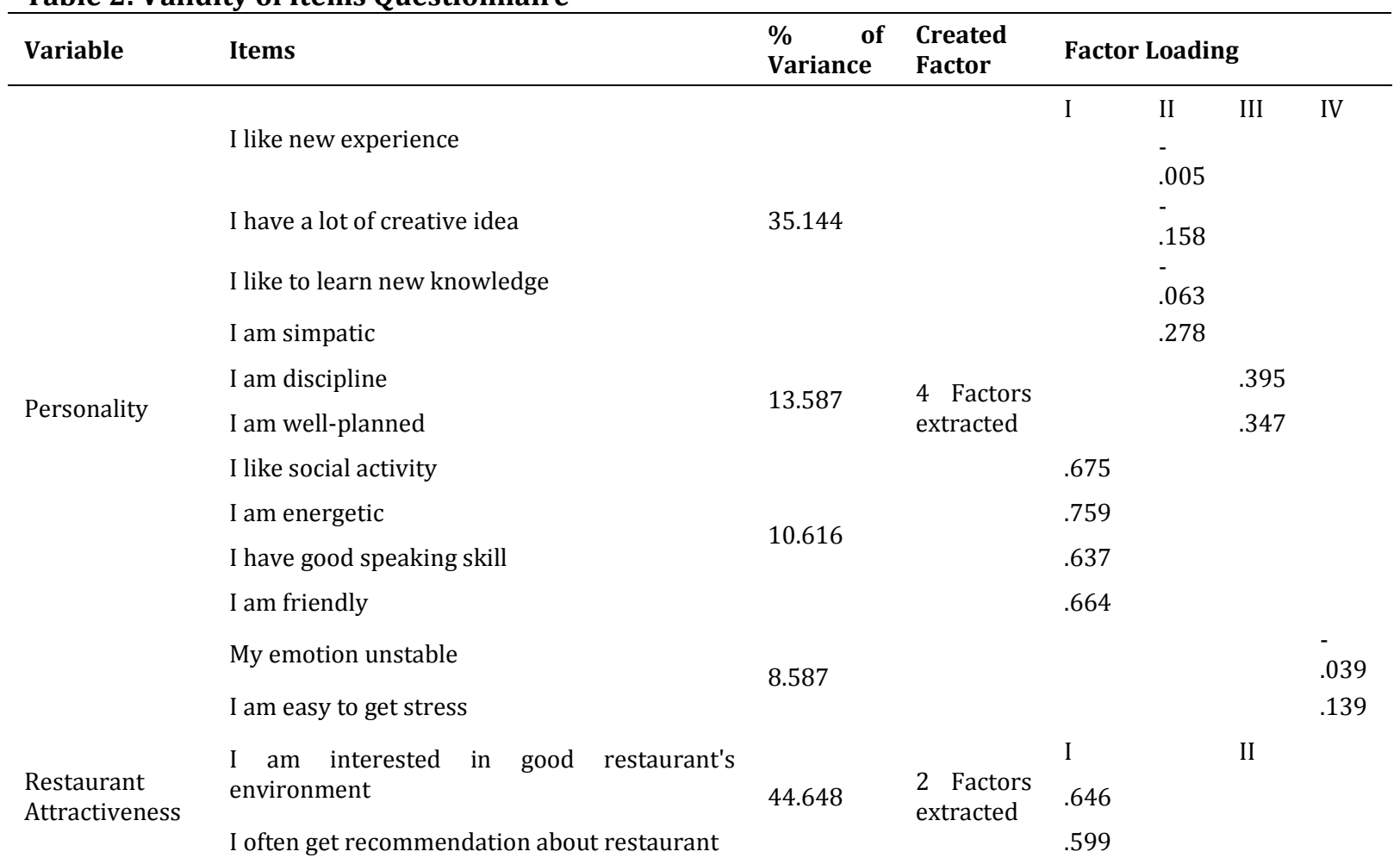




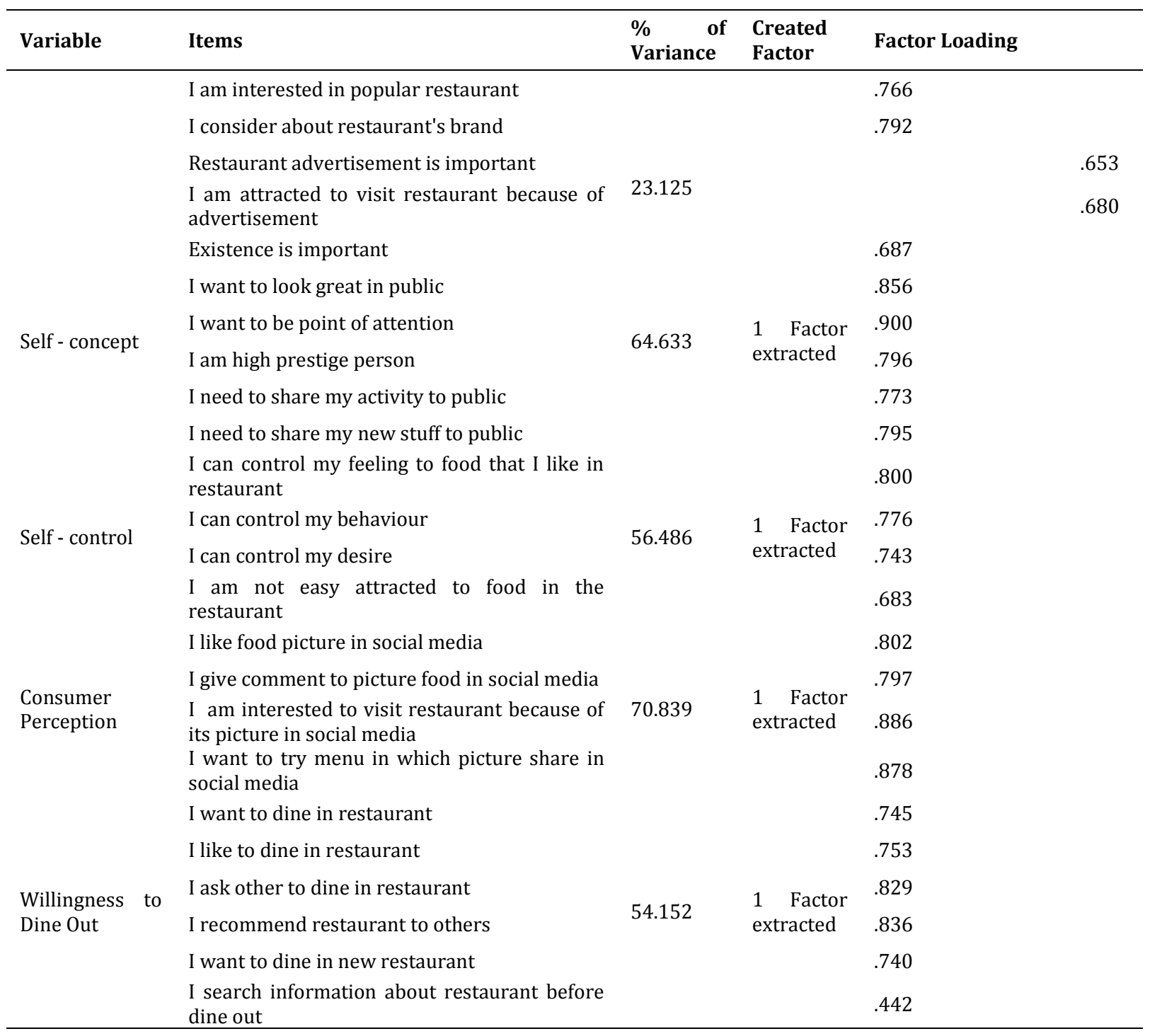

After reducing factor and eliminating invalid items, we categorized new factors. Detail information is explained by following table:

Table 3: Validation Using Exploratory Factor Analysis

\begin{tabular}{llllll}
\hline Variable & KMO & $\begin{array}{l}\text { Bartlett's Test } \\
\text { Chi Square }\end{array}$ & df & Sig & Created Factor \\
\hline Social Personality & .772 & 131.928 & 6 & .000 & Attractive Popularity \\
Restaurant Attractiveness & .672 & 186.273 & 15 & .000 & Attractive Advertising \\
Self - concept & .844 & 342.900 & 15 & .000 & \\
Self - control & .709 & 91.535 & 6 & .000 & \\
Consumer Perception & .767 & 198.775 & 6 & .000 & \\
Willingness to Dine Out & .809 & 221.553 & 15 & .000 & \\
\hline
\end{tabular}

Based on KMO value, which are all above .6, the data set in all variables, are suitable for factor analysis (Pallant, 2011). All variables are significant and it is validated. In variable company attractiveness is divided into two factor and will count as different variable in the next measurement. 
Table 4: Reliability Test

\begin{tabular}{ll}
\hline Variable & Cronbach's Alpha \\
\hline Social Personality & .805 \\
Restaurant Attractiveness & .745 \\
Self - concept & .888 \\
Self - control & .736 \\
Consumer Perception & .859 \\
Willingness to Dine Out & .820 \\
\hline
\end{tabular}

According to Table 4 shown the Cronbach Alpha are above .7, means that all variables are reliable (De Vellis, 2003). Reliability scale varies depending on the sample (Pallant, 2011). Based on this study all the variable has good result of reliability. Based on following explanation, relationship among variables were measure using proposed conceptual framework:

Figure 1: Proposed Conceptual Framework

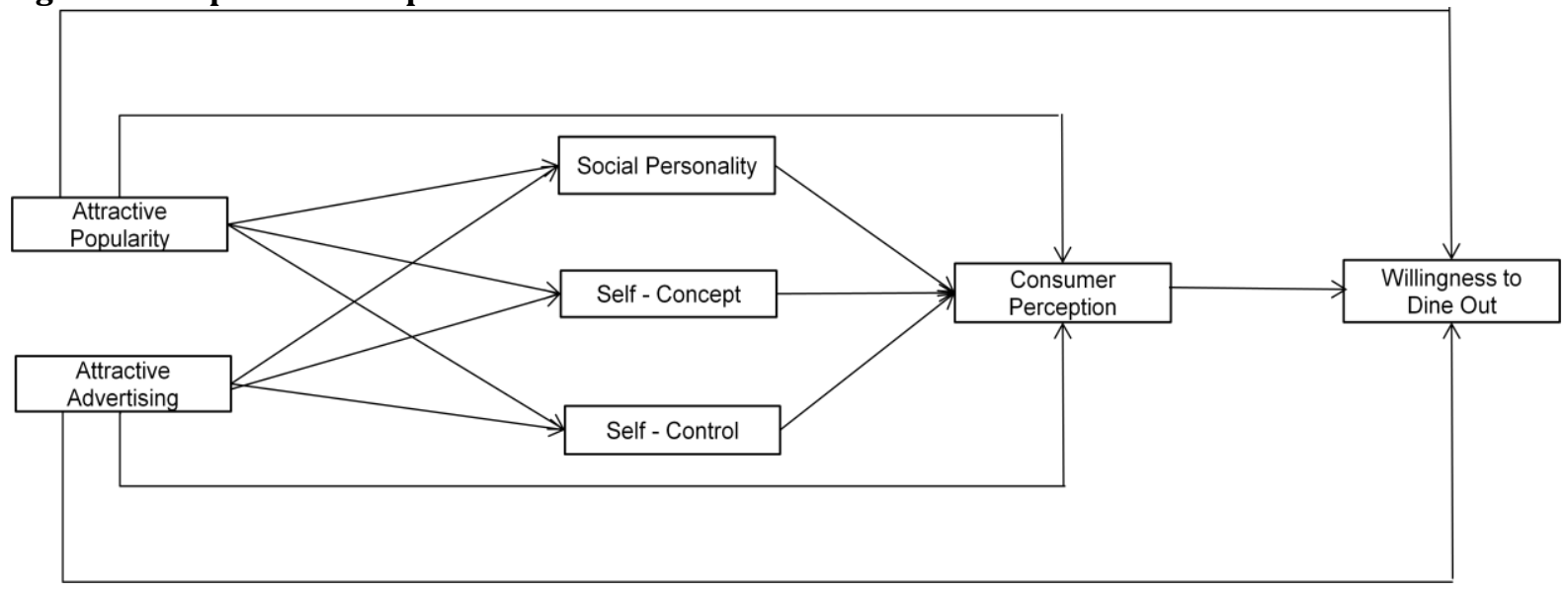

\section{Results}

In order to analyze data to detect which variables are significantly affect consumer's willingness to dine out, multiple regression analysis was conducted. The result of the analysis shown in Table.5:

Table 5: Regression

\begin{tabular}{|c|c|c|c|c|c|c|}
\hline Independent Variable & $\begin{array}{l}\text { Dependent } \\
\text { Variable }\end{array}$ & Beta & $\begin{array}{l}\mathrm{R} \\
\text { Square }\end{array}$ & $\begin{array}{l}\text { Sig } \\
\text { Coefficient }\end{array}$ & $\mathbf{t}$ & $\mathbf{F}$ \\
\hline Attractive Popularity & \multirow{2}{*}{ Social Personality } & $.329^{* *}$ & \multirow{2}{*}{.112} & .001 & 3.469 & \multirow{2}{*}{6.243} \\
\hline Attractive Advertising & & .064 & & .502 & .674 & \\
\hline Attractive Popularity & \multirow{2}{*}{ Self - concept } & $.210^{* *}$ & \multirow{2}{*}{.198} & .022 & 2.332 & \multirow{2}{*}{12.251} \\
\hline Attractive Advertising & & $.393^{* * *}$ & & .000 & 4.366 & \\
\hline Attractive Popularity & \multirow{2}{*}{ Self - control } & .082 & \multirow{2}{*}{.014} & .411 & .826 & \multirow{2}{*}{.713} \\
\hline Attractive Advertising & & .086 & & .391 & .862 & \\
\hline Self - control & \multirow{5}{*}{$\begin{array}{l}\text { Consumer } \\
\text { Perception }\end{array}$} & .101 & \multirow{3}{*}{.156} & .309 & 1.022 & \multirow{3}{*}{6.038} \\
\hline Self - concept & & $.296^{* *}$ & & .003 & 3.061 & \\
\hline Social Personality & & .146 & & .159 & 1.421 & \\
\hline Attractive Popularity & & $.405^{* * *}$ & \multirow{2}{*}{.288} & .000 & 4.772 & \multirow{2}{*}{20.067} \\
\hline Attractive Advertising & & $.353^{* * *}$ & & .000 & 4.166 & \\
\hline Consumer Perception & \multirow{3}{*}{$\begin{array}{l}\text { Willingness } \\
\text { Dine Out }\end{array}$} & $.496^{* * *}$ & .238 & .000 & 5.709 & 32.591 \\
\hline Attractive Popularity & & $.624^{* * *}$ & \multirow{2}{*}{.379} & .000 & 7.954 & \multirow{2}{*}{31.758} \\
\hline Attractive Advertising & & .039 & & .622 & .494 & \\
\hline
\end{tabular}

***: correlation significant at the .000 level; **: at the.01-.05 level 
Based on Table 5 not all variables were significant affect too dependent variables. Attractive popularity was significantly affect social personality. Attractive advertising was significantly affect self-concept. None of attractive popularity or attractive advertising significantly affects self-control. Self-concept, attractive popularity and attractive advertising were significantly affect consumer perception. Willingness to dine out was affected significantly by consumer perception and attractive popularity. According to variables, which are significant, new framework design to describe relation among variables?

Figure 2: Relation Among Variables

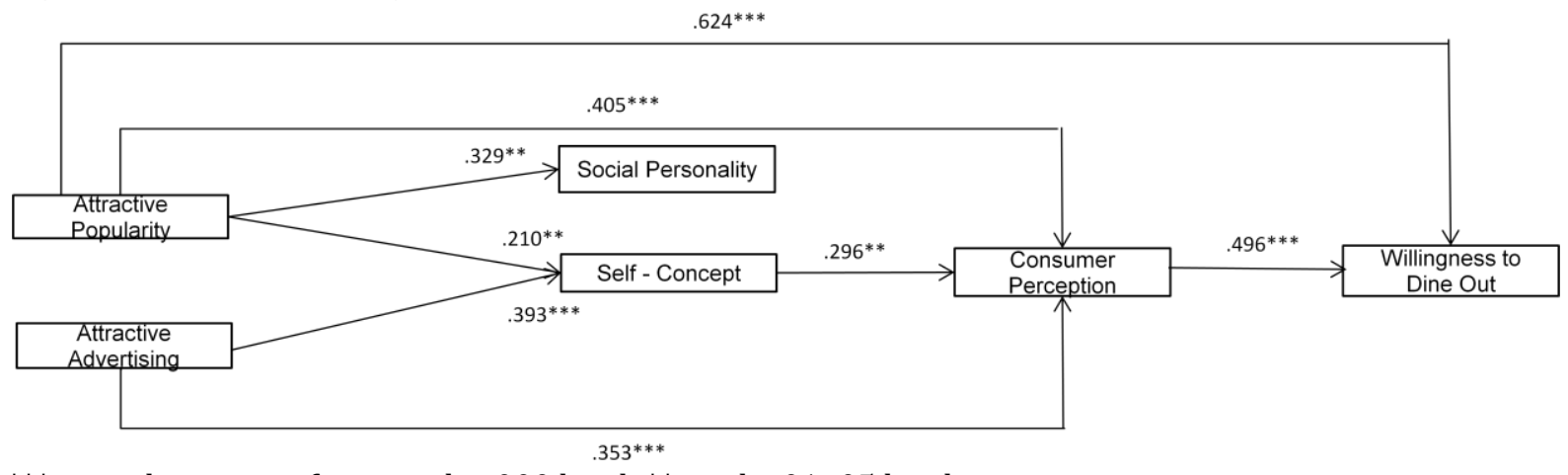

***: correlation significant at the .000 level; ${ }^{* *}$ : at the.01-.05 level

Restaurant attractiveness differed into two factors: attractive popularity and attract advertising. Attractive popularity significantly affect social personality, means that restaurant environment, recommendation from others and restaurant's brand affect personality of the consumer and customer's self-concept. Attractive advertising showed the importance of advertising and attractive advertisement affect to self-concept significantly. Different restaurant attractiveness will determine different personality of consumer. Therefore, in this case, restaurant need to match their attribute to segmented consumer. These two factors of restaurant attractiveness have direct significant effect to consumer perception. Attractive popularity also have direct significant affect to willingness to dine out. For detail information of effect among variables will be presented in Table 6:

Table 6: Result of Regression Analysis

\begin{tabular}{|c|c|c|c|c|c|c|c|c|}
\hline Independent & Intervening 1 & Intervening 2 & Dependent & $\begin{array}{l}\text { Indirect } \\
\text { ind- int }\end{array}$ & $\begin{array}{l}\text { int- } \\
\text { int }\end{array}$ & $\begin{array}{l}\text { int- } \\
\text { dep }\end{array}$ & Direct & $\begin{array}{l}\text { Total } \\
\text { Effect }\end{array}$ \\
\hline Attractive Popularity & Self - concept & - & $\begin{array}{l}\text { Consumer } \\
\text { Perception }\end{array}$ & .210 & - & .296 & .405 & .4672 \\
\hline Attractive Advertising & Self - concept & - & $\begin{array}{l}\text { Consumer } \\
\text { Perception }\end{array}$ & .393 & - & .296 & .353 & .4693 \\
\hline Attractive Popularity & Self - concept & $\begin{array}{l}\text { Consumer } \\
\text { Perception }\end{array}$ & $\begin{array}{c}\text { Willingness to } \\
\text { dine out }\end{array}$ & .210 & .296 & .496 & .624 & .6548 \\
\hline
\end{tabular}

Attractive popularity gave more direct effect consumer perception rather than attractive advertising. From Table.6 the biggest effect of willingness to dine out were affected by the following variables of attractive popularity, self-concept, and consumer perception directly and directly. From the explanation and the result of analysis of regression, hypothesis tested.

Table 7: Summary of Hypothesis

\begin{tabular}{lll}
\hline Hypothesis & Result \\
\hline $\mathrm{H}_{1 \mathrm{a}}$ & Restaurant attractiveness will significantly affect the consumer perception. & Supported \\
$\mathrm{H}_{1 \mathrm{~b}}$ & Restaurant attractiveness will significantly affect willingness to dine out. & Supported \\
$\mathrm{H}_{2}$ & Personality will significantly affect consumer perception & Not Supported \\
$\mathrm{H}_{3}$ & Self - concept will significantly affect consumer perception & Supported \\
$\mathrm{H}_{4}$ & Self-control will significantly affect consumer perception. & Not Supported \\
$\mathrm{H}_{5}$ & Consumer perception significantly affect willingness to dine out & Supported \\
\hline
\end{tabular}

Restaurant attractiveness is associated to both consumer perception and willingness to dine out. It means that attractiveness of the restaurant need to be develop and it is one of the key factor to attract consumer to dine out. Personality which explained by social personality and self-control didn't make greater effort 
to consumer perception. Consumer perception need to be improved to increase consumer's willingness to dine out.

\section{Conclusion}

This study investigated affect of internal and external factor of consumer through consumer perception to willingness to dine out. Where the internal factors were measured by using consumers' self-concept, selfcontrol, personality it's self through consumer perception. In addition, the external factor was measured by using restaurant attractiveness. Based on regression analysis showed that not all internal factors significantly affect willingness to dine out through customer perception, only self-concept affect consumer perception and affect willingness to dine out. Restaurant attractiveness have directly effect to consumer's perception. Restaurant's manager need to give attention to the attractiveness of the restaurant and consider about the right segmented consumer as their priority to serve. Self-concept referred to how consumer having reference about their self (Rosenberg, 1979), so that restaurant needs to support consumer self-concept to increase their good perception about the restaurant and increase their willingness to dine out.

Managerial Implications: This research has important implications for designing marketing program in restaurant or other service company, which closely related to social media for promotion like on Facebook, Twitter, Path, etc. Using social media as promotion place to attract consumer can be implemented by uploading photos of product and service in that company. A broad factor of what consider consumer to dine out is beyond scope of this paper. Choosing right marketing program to right consumer will lead company to gain more sales and competitive advantage rather than other rivals. Popularity of company need to be maintain to set good perception in consumer's mind. A better understanding about consumer's willingness to dine out may help company growth and sustainability.

Limitation and Future Research: This study support theoretical views of willingness to dine out by identifying consumer self-concept, self-control, and personality, restaurant attractiveness through consumer perception. Further research might the concerned to question to be generalized, due to number of sample. Another possible concerned by adding other self-concept factor. Experimental methodology might combined to this kind of study because experimental is ideal for examining customer's behaviour in short-term mood state. More studies on relationship and effect among variables needed to cross-validate the finding from different directions and situations. Number of sample and the coverage of study need to be increased to generalize the finding of the study.

\section{Reference}

Aaker, D. (1996). Building Strong Brands: The Free Press, New York, NY.

Ahuvia, A. (2005). Beyond the Extended Self: Love Objects and Consumer's Identity Narratives.

Andreassen, T. W. \& Lervik, L. (1999). Perceived relative attractiveness today and tomorrow as predictors of future repurchase intention. Journal of Service Research, 2(2), 164-72.

Anreassen, T. \& Olsen, L. (2008). The Impact Of Consumer's Perception of Varying Degree of Consumer Service On Commitment and Perceived Relative Attractiveness. Managing Service Quality, 18 (4), 309-328.

Boyd, D. \& Ellison, N. (2007).Social network sites: definition, history, and scholarship. Journal of Computer - Mediated Communication, 13(1), 210-30.

Carman, J. M. (1990). Consumer perception of service quality: an assessment of the SERVQUAL dimensions. Journal of Retailing, 66(1), 33-45.

DeVellis, R. F. (2003). Scale development: Theory and applications (2nd edn). Thousand Oaks, California: Sage.

Dube, L., Renaghan, L. M. \& Miller, J. M. (1994). Measuring consumer satisfaction for strategic management. The Cornell Hotel and Restaurant Administration Quarterly, 35(1), 39-47.

Dulen, J. (1999). Quality control. Restaurant \& Institutions, 109(5), 38-52.

Fu, Y. Y. \& Parks, S. C. (2001). The relationship between restaurant service quality and consumer loyalty among the elderly. Journal of Hospitality and Tourism Research, 25(3), 320-336.

Gosling, S. D., Rentfrow, P. J. \& Swann, W. B. Jr. (2003). A Very Brief Measure of the Big Five Personality Domains. Journal of Research in Personality, 37, 504-528. 
Greenwald, A. G. (1989). Why Attitude Are Important: defining attitude and attitude theory twenty years later, in Pratkanis, A.R, Brecker and Greenwald, Attitude Structure and Function, Erlbaum, Hillsdale, NJ, 429-440.

Hair, J. \& Black, W. (2006). Multivariate Data Analysis: Pearson Prentice Hall

Johnson, M. D., Gustafson, A., Andreassen, T. W., Lervik, L. \& Cha, J. (2001). The evolution and future of national consumer satisfaction indices. Journal of Economic Psychology, 22(2), 217-45.

Kaufman, C. S. (2002).E-shopping image multiple channel environment. Journal of Consumer Marketing, $19(4), 333-350$.

Kivela, J., Reece, J. \& Robert, I. (1999). Consumer research in the restaurant environment. Part 2: Research design and analytical methods. International Journal of Contemporary Hospitality Management, 11(6), 269-286

Lee, J. \& Allaway, A. (2002). Effects of personal control on adoption of self- service technology innovations. Journal of Services Marketing, 16(6), 553-72.

McShane, S. L. \& von Glinow, M. A. (2010). Organizational Behavior (5th Edition). McGraw-Hill.

Namkung, Y. \& Jang, S. (2007). Are highly satisfied restaurant consumers really different? A quality perception perspective. International Journal of Contemporary Hospitality Management, 20(2), 142-155.

Olson, J. C. (1977). Price as an informational cue: effects in product evaluation, in Woodside, A., Sheth, J. and Bennet, P. (Eds), Consumer and Industrial Buying Behavior, North Holland .Publishing Company, New York, NY.

Olson, J. C. \& Jacoby, J. (1972). Cue utilization in the quality perception process.paper presented at Third Annual Conference of the Association for Consumer Research Association for Consumer Research, Iowa City.

Pallant, J. (2011). Survival Manual A step by Step Guide to Data Analysis Using SPSS ( $4^{\text {th }}$ ed). Allen \& Uwin: Crows Nest.

Palmer, A. \& Lewis, N. (2009). An experiential, social network-based approach to direct marketing. Direct Marketing: An International Journal, 3(3), 162-176.

Pappu, R. \& Quester, P. (2006). A consumer based method for the retailer equity measurement: results of an empirical study. Journal of Retailing and Consumer Services, 13(5), 317-29.

Parasuraman, A., Zeithaml, V. \& Berry, L. (1988). SERVQUAL: a multiple-item scale for measuring consumer perceptions of service quality. Journal of Retailing, 64(1), 12-40.

Porter, L. W., Steers, R. M., Mowday, R. T. \& Boulian, P. V. (1974).Organizational commitment, job satisfaction, and turnover among psychiatric technicians. Journal of Applied Psychology, 56(5), 603-9.

Rahman, M. (2012). Dynamics of consumer's perception, demographic characteristics and consumers' behavior towards selection of a restaurant: an exploratory study on Dhaka city consumers. Business Strategy Series, 13(2).

Rajagopal, G. (2006). Brand excellence: measuring the impact of advertising and brand personality on buying decisions. Measuring Business Excellence, 10(3), 56-66.

Robbins, S. P. (2005). Organizational Behavior, (11th Edition), Pearson Prentice Hall

Rosenberg, M. (1979). Conceiving the Self, Basic Books, New York, NY.

Schiffman, G. L. \& Kanuk, L. L. (2000). Consumer Behavior (7th ed). Prentice Hall, Upper Saddle River, NJ

Shwu-Ing, W. (2003).The relationship between consumer characteristics and attitudes toward online shopping. Marketing Intelligence \& Planning, 21(10), 37-44.

Sirgy, M. J. (1982). Self - Concept in Customer Behavior: a critical review. Journal of Consumer Research, 9, 287-299.

Solomon, M. R. (2011). Consumer Behavior (9th global edition) Prentice Hall, Englewood Cliffs, NJ.

Susskind, A. M. \& Chan, E. K. (2000). How restaurant features affect check averages: a study of the Toronto restaurant market.The Cornell Hotel and Restaurant Administration Quarterly, 41(6), 56-63.

Tam, J. L. M. (2004).Consumer satisfaction, service quality and perceived value: an integrative model. Journal of Marketing Management, 20(7), 897-917.

Yoo, B. H., Donthu, N. \& Leee, S. H. (2000).An examination of selected marketing mix elements and brand equity. Journal of the Academy of Marketing Science, 28(2), 195-211. 